\title{
ANALISIS HUBUNGAN PERAN PETUGAS KESEHATANDENGAN CAKUPAN IMUNISASI PADA BAYI SELAMA PANDEMI COVID-19
}

\author{
Retno Setyo Iswati \\ Prodi S1 Kebidanan, Universitas PGRI Adi Buana Surabaya \\ e-mail: retnoiswati@unipasby.ac.id
}

\begin{abstract}
During the Covid-19 pandemic, social restrictions applied in various regions affected the schedule and procedures for immunization services in health facilities. People are worried that coming to health facilities to provide immunizations for their children, causing immunization coverage to fall so that community immunity is not formed, can lead to Extraordinary Events of Diseases that Can Be Prevented by Immunization (KLB PD3I). Health workers in providing immunization services play a very important role in the success of the immunization program. The aim of the study was to analyze the relationship between the role of health workers and the complete basic immunization coverage during the Covid-19 pandemic. The research design used was a survey method with a quantitative approach. The sample was 46 respondents, the sample was taken using purposive sampling. The research instrument consisted of the role of health workers and complete basic immunization coverage which was distributed online. Data were analyzed using the Chi-Square test. The result of the research found that the role of health workers in providing immunization services was in the "Good" category (67.4\%), complete basic immunization coverage was in the "Less" category (71.7\%), so it can be concluded that there is no relationship between the role of health workers and the coverage. complete basic immunization during the Covid-19 pandemic
\end{abstract}

Keywords: role of health workers, immunization coverage, Covid-19 pandemic

\begin{abstract}
ABSTRAK
Pada masa pandemi Covid-19 pembatasan sosial yang diterapkan diberbagai daerah berpengaruh pada jadwal serta tata cara pemberian imunisasi di fasilitas-fasilitas kesehatan. Masyarakat khawatir untuk datang ke fasilitas kesehatan untuk memberikan imunisasi bagi anaknya, menyebabkan cakupan imunisasi turun sehingga kekebalan komunitas tidak terbentuk, hal tersebut dapat menyebabkan terjadinya Kejadian Luar Biasa Penyakit yang Dapat Dicegah Dengan Imunisasi ( KLB PD3I). Petugas kesehatan dalam memberikan pelayanan imunisasi berperan sangat penting untuk keberhasilan program imunisasi.Tujuan penelitian adalah menganalisis hubungan peran petugas kesehatan dengan cakupan imunisasi dasar lengkap selama pandemi Covid - 19. Desain penelitian yang digunakan adalah metode survei dengan pendekatan kuantitatif. Sampel berjumlah 46 responden, pengambilan sampel menggunakan purposive sampling. Instrumen penelitian terdiri dari peran petugas kesehatan dan cakupan imunisasi dasar lengkap yang disebarkan secara online. Data dianalisis menggunakan uji Chi-Square. Hail penelitian didapatkan peran petugas kesehatan dalam memberikan pelayanan imunisasi dengan kategori "Baik" (67,4\%), cakupan imunisasi dasar lengkap dalam kategori "Kurang” (71,7 \%), sehingga dapat disimpulkan tidak ada hubungan antara peran petugas kesehatan dengan cakupan imunisasi dasar lengkap selama pandemi Covid-19
\end{abstract}

Kata kunci: peran petugas kesehatan, cakupan imunisasi, pandemi Covid-19

\section{PENDAHULUAN}

\section{Latar Belakang (Opsional)}

Krisis masalah kesehatan terbesar dunia saat ini adalah Covid-19 merupakan infeksi virus SARSCov-2 (Severe Acute Respiratory Syndrome Coronavirus-2)Penyakit ini diketahui pertama kali di Wuhan, China dan WHO menyatakan sebagai pandemi pada bulan Maret 2020. Di negara China, Korea Selatan serta Itali, data pasien terkonfirmasi
Covid-19 menunjukkan lebih sedikit terjadi pada anak yang usianya kurang dari 10 tahun dan bila terkena gegalanya tidak berat. Ikatan Dokter Anak Indonesia melaporkan data di Indonesia pertanggal 23 Mei 2020 anak yang terkonfirmasi Covid-19terdapat $>0.1 \%$. Beberapa penemuan melaporkan bayi yang usianyakrang dari 1 tahun rentan terkena infeksi Covid-19 dan bila terinfeksi biasanya gejalanya lebih berat dibandingkan anak-anak. sampai usia 6 tahun [1]. 
Di Indonesia, Covid-19 ditetapkan sebagai kejadian bencana berupa pandemi. Berbagai upaya dilakukan untuk mencegah penyebaran virus conana melalui pembatasan sosial, antara lain pemberlakuan isolasi, penundaan acara yang meibatkan banyak orang, pembatasan kerumunan, pembatasan perjalanan, penutupan fasilitas, dan pengaturan pelayanan publik. Upaya - upaya pengendalian Covid-19 tersebut menimbulkan dampak diberbagai sektor. Salah satu pelayanan kesehatan yang terdampak adalah program imunisasi. Pembatasan sosial yang diterapkan diberbagai daerah berpengaruh pada jadwal serta tata cara pemberian imunisasi di fasilitas-fasilitas kesehatan. Masyarakat khawatir untuk datang ke fasilitas kesehatan untuk memberikan imunisasi bagi anaknya, dan jika kondisi tersebut dibiarkan terus menerus, menyebabkan cakupan imunisasi secara nasional mengalami penurunanakibatnyaherd immunity tidak terbentuk, kondisi hal tersebut dapat menyebabkan terjadinya Kejadian Luar Biasa Penyakit yang Dapat Dicegah Dengan Imunisasi ( KLB PD3I) seperti Campak, Rubela, Difteri, Polio, dan lainnya. [2]

Di era pandemi Covid-19, pelayanan imunisasi tetap dilaksanakan sesuai jadwal usia bayi untuk melindungi anak dari penyakit yang dapat dicegah dengan imunisasi (PD3I). Pelayanan imunisasi dilakukan sesuai dengan prinsip Pencegahan dan Pengendalian Infeksi (PPI) serta physical distancing yaitu menjaga jarak antara $1-2$ meter. Dalam memberikan pelayanan imunisasi tenaga kesehatan berperan sangat penting untuk keberlangsungan kegiatan tersebut. Berdasarkan referensi yang didapat menunjukkan bahwa perlu dilakukan kajian mengenai peran petugas kesehatan dalam program imunisasi selama pandemi Covid-19. Peran petugas kesehatan dipandang sebagai sebagai proses dan cakupan imunisasi dipandang sebagai output, sedangkan input tidak dikaji. Hal ini didasarkan atas pendapat Azwar, yang mendeskripsikan model pendekatan system terdiri atas unsur utama input, proses dan output [3].

Oleh karena itu tujuan penelitian ini adalah menganalisis hubungan peran petugas kesehatan dengan cakupan imunisasi dasar lengkap selama pandemi Covid - 19 .

\section{Tujuan Penelitian (Opsional)}

Tujuan penelitian ini adalah menganalisis hubungan peran petugas kesehatan dengan cakupan imunisasi dasar lengkap selama pandemi Covid - 19 .

\section{METODE}

Penelitian ini menggunakan metode survei dengan pendekatan kuantitatif. Data yang digunakan adalah data primer, menggunakan instrument kuesioner. Kuesioner merupakan petanyaan yang disusun secara sitematis diberikan respondenuntuk dijawab [4]. Pengambilan data dengan kusioner digunakan bila responden tersebar dan dalam jumlah yang cukup besar. Kuesioner disebarkan bertujuan mendapatkan data tentang peran petugas kesehatan dalam memberikan pelayanan imunisasi pada bayi selama pandemi Covid-19 dan cakupan imunisasi. Teknik pengambilan sampel menggunakan teknik purposive sampling, yaitu pemilihan sampel dengan pertimbangan tertentu, yaitu petugas kesehatan adalah bidan atau perawat yang bekerja di Posyandu, Polindes/Poskesdes, Puskemas, Praktik Mandiri Bidan, Klinik Pratama, dan Rumah Sakit. Pertimbangannya adalah bidan atau perawat tersebut bekerja di fasilitas kesehatan yang memberikan pelayanan imunisasi pada bayi. Kuesioner dibuat menggunakan google form dan disebarkan secara online melalui whatsapp, dikarenakan pada masa pandemi Covid-19 tidak memungkinkan untuk menyebarkan kuesioner secara langsung. Dalam waktu 1 bulan penyebaran kuesioner didapatkan 46 orang responden. Penyebaran kuesioner mulai tanggal 07 Juli - 07 Agustus 2020. Instrumen kuesioner berupa 10 pertanyaan tertutup. Pertanyaan meliputi peran petugas kesehatan sebelum dan selama memberikan pelayanan imunisasi. Pengukuran variabel penelitian menggunakan skala Likert, sehingga variabel yang akan diukur dijabarkan menjadi sub variabel. Data diolah dengan menggunakan program Excel untuk dihitung indeksnya, Interval penilaian pada peran petugas kesehatan, adalah "Baik" jika didapatkan indeks : 80 - 100\%, "Cukup baik" jika didapatkan indeks : 60 79\%, dan "Kurang" jika : $0-59 \%$, sedangkan data cakupan imunisasi dengan "kategori baik"jika indeksnya $100-80 \%$ dan kategori kurang jika indeksnya $0-79 \%$. Analisa data menggunakan uji korelasi Chi Square, dengan tingkat signifikansi $\alpha=$ 0,05

\section{HASIL}

Tabel 1. Karakteristik responden berdasarkan umur, tingkat pendidikan dan tempat bekerja

\begin{tabular}{lcc}
\hline Karakteristik & $\begin{array}{c}\mathrm{F} \\
(\mathrm{n}=46)\end{array}$ & $\begin{array}{c}\% \\
(\mathrm{n}=100)\end{array}$ \\
\hline Umur & & \\
$\quad<35$ tahun & 22 & 47,82 \\
$\quad \geq 35$ tahun & 24 & 52,18 \\
Tingkat Pendidikan & & \\
D3 & 29 & 63,04 \\
D4 & 12 & 26,09 \\
S1 & 2 & 4,35 \\
S2 & 3 & 6,52 \\
Tempat Bekerja & &
\end{tabular}




\begin{tabular}{lcc} 
Rumah Sakit & 4 & 8,70 \\
Klinik Pratama & 3 & 6,52 \\
Puskesmas & 20 & 43,48 \\
Polindes/Poskesdes/Pustu & 11 & 23,91 \\
Posyandu & 1 & 2,17 \\
Praktik Mandiri Bidan & 7 & 15,22 \\
\hline
\end{tabular}

Analisis karakteristik responden dari tabel 1 diketahui bahwa dari total responden sebanyak 46 orang, sejumlah 24 orang $(52,18 \%)$ berusia $\geq 35$ tahun, memiliki pendidikan terakhir Diploma III, baik Diploma III Kebidanan maupun Diploma III sebanyak 29 orang $(63,04 \%)$ dan bekerja di Puskesmas sebanyak 20 orang $(43,48 \%)$

Tabel 2. Peran Petugas Kesehatan Dalam Memberikan Pelayanan Imunisasi

\begin{tabular}{lcc}
\hline Peran Petugas Kesehatan & f & $\%$ \\
\hline Baik & 31 & 67,4 \\
Cukup baik & 15 & 32,6 \\
Jumlah & 46 & 100 \\
\hline
\end{tabular}

Berdasarkan tabel 2 dapat dilihat bahwa sebagian besar responden menunjukkan perannya dalam memberikan pelayanan imunisasi dengan kategori "Baik" $(67,4 \%)$

Tabel 3. Indeks Peran Petugas Kesehatan

\begin{tabular}{lrcc}
\hline Pernyataan & & f & $\%$ \\
\hline Pertugas & Kesehatan & 44 & 98,55 \\
menginfokan & tentang jadwal & & \\
imunisasi pada & masa pandemi & &
\end{tabular}

Petugas Kesehatan melakukan 4297,10 penjadwalan imunisasisupaya kedatangan sasaran imunissi dapat diatur serta pelayanan berjalan lancar (melaui handphone, Whatsapp, pesan singkat, dll) . Pembatasan $10-$ 20 sasaran imunisasi per-sesi

\begin{tabular}{lccc}
\hline $\begin{array}{l}\text { Mengukur suhu bayi dan } \\
\text { pengantar } \\
\text { termogun }\end{array}$ & 37 & 92,75 \\
& & & \\
\hline $\begin{array}{l}\text { Mengingatkan orangtua atau } \\
\text { pengantar untuk membawa anak }\end{array}$ & 45 & 98,55 \\
ke tempat pelayanan Kesehatan \\
dengan membawa kartu \\
imunisasi
\end{tabular}

\begin{tabular}{|c|c|c|}
\hline kesehatan & & \\
\hline $\begin{array}{l}\text { Menggunakan handschoen (bila } \\
\text { tersedia), dan diganti per satu } \\
\text { sasaran imunisasi }\end{array}$ & 30 & 86,23 \\
\hline $\begin{array}{l}\text { Memastikan logistik, vaksin, } \\
\text { serta peralatan anafilaktik cukup } \\
\text { tersedia dan berfungsi baik }\end{array}$ & 46 & 100 \\
\hline $\begin{array}{l}\text { Melakukan skrining COVID-19 } \\
\text { secara singkat tentang kondisi } \\
\text { kesehatan sasaran sebelum } \\
\text { imunisasi }\end{array}$ & 42 & 96,37 \\
\hline $\begin{array}{l}\text { Memberikam informasi apabila } \\
14 \text { hari sesudah pemberian } \\
\text { imunisasi } \\
\text { COVID-19 atau ada gejala } \\
\text { COVID-19 , pada tenaga } \\
\text { kesehatan, kader maupun } \\
\text { pengantar/orangtua harus segera } \\
\text { menghubungi tenaga kesehatan }\end{array}$ & 42 & 96,37 \\
\hline
\end{tabular}

Diketahui sub variabel peran petugas kesehatan didapatkan indeks tertinggi (100\%) yaitu pada petugas kesehatan dan pengantar wajib memakai masker di tempat pelayanan kesehatan dan memastikan seluruh vaksin, logistik sertaperlengkapan/kit anafilaktik ada dalam kondisi baik serta bersih, sedangkan indeks terendah $(86,23 \%)$ yaitu menggunakan sarung tangan (bila tersedia), sarung tangan diganti setiap satu sasaran yang diimunisasi. Hal ini dapat dilihat pada tabel 3.

Tabel 4. Cakupan Imunisasi Dasar Lengkap

\begin{tabular}{lcc}
\hline Kategori & $\mathrm{f}$ & $\%$ \\
\hline Baik & 13 & 28,3 \\
\hline Kurang & 33 & 71,7 \\
\hline Jumlah & 46 & 100 \\
\hline
\end{tabular}

Penelitian ini menunjukkan bahwa cakupan imunisasi dasar lengkap dinilai dari indeks cakupan imunisasi per-antigen dari 46 orang,sebagian besar responden yaitu sebanyak 33 orang memiliki kategori kurang $(71,7 \%)$ dan sebanyak 13 orang memiliki kategori baik $(28,3 \%)$

Tabel 5. Indeks Cakupan Imunisasi Dasar Lengkap

\begin{tabular}{lll}
\hline Cakupan & $\mathrm{f}$ & $\%$ \\
\hline
\end{tabular}



Vol. 15 No. 3 September - Desember 2020

\begin{tabular}{lcc}
\hline Imunisasi/antigen & & \\
\hline HB0 & 32 & 84,78 \\
\hline BCG & 24 & 76,09 \\
\hline DPT 1 & 22 & 73,91 \\
\hline DPT 2 & 19 & 70,65 \\
\hline DPT 3 & 24 & 76,08 \\
\hline Polio & 24 & 76,08 \\
\hline Campak & 21 & 72,83 \\
\hline \multicolumn{4}{l}{ Tabel } & menunjukkan indeks cakupan \\
imunisasi dasar & lengkap tertinggi pada cakupan \\
imunisasi HB0 (84,78\%) dan indeks terendah pada \\
cakupan imunisasi DPT 2 (70,65\%)
\end{tabular}

Tabel 6. Tabulasi silang Hubungan Peran Petugas Kesehatan Dengan Cakupan Imunisasi Dasar lengkap

\begin{tabular}{|c|c|c|c|c|c|c|c|c|}
\hline & & \multicolumn{4}{|c|}{ Cakupan Imunisasi } & \multirow{2}{*}{\multicolumn{2}{|c|}{ Total }} & \multirow{2}{*}{$\begin{array}{c}p- \\
\text { value }\end{array}$} \\
\hline & & \multicolumn{2}{|c|}{ Baik } & \multicolumn{2}{|c|}{ Kurang } & & & \\
\hline & & $\mathrm{f}$ & $\%$ & $\mathrm{f}$ & $\%$ & $\mathrm{f}$ & $\%$ & \\
\hline Peran & Baik & 7 & 15,2 & 24 & 52,2 & 31 & 67,4 & 0.21 \\
\hline $\begin{array}{l}\text { Petugas } \\
\text { Kesehatan }\end{array}$ & $\begin{array}{c}\text { Cukup } \\
\text { Baik }\end{array}$ & 6 & 13,1 & 9 & 19,5 & 15 & 32,6 & \\
\hline Total & & 13 & 28,3 & 33 & 71,7 & 46 & 100 & \\
\hline
\end{tabular}

Tabel 6 menunjukkan dari total 31 responden $(67,4 \%)$ yang berperan baik, menghasilkan cakupan imunisasi kurang sebesar 24 responden $(52,2 \%)$. Hasil analisis menggunakan uji Chi Square menunjukkan nilai probabilitas sebesar 0.21 atau nilai $p$ lebih besar dari 0.05 sehingga $\mathrm{H} 0$ diterima yang artinya tidak ada hubungan antara peran petugas kesehatan dengan cakupan imunisasi dasar lengkap selama pandemi Covid-19.

\section{PEMBAHASAN}

Pada penelitian ini responden yang diambil adalah tenaga kesehatan yang sebagian besar bekerja di Puskesmas dan menunjukkan perannya dalam memberikan pelayanan imunisasi dengan kategori "Baik" Menurut Permenkes RI No. 42 tahun 2013 tentang Penyelenggaraan Imunisasi menyebutkan bahwa pemberian imunisasi harus dilakukan berdasarkan standar pelayanan, standar prosedur operasional dan standar profesi sesuai ketentuan peraturan perundangan. Proses pelayanan imunisasi wajib mencermati keamanan vaksin serta penyuntikan agar tidak terjadi penularan penyakit terhadap tenaga kesehatan pelaksana pelayanan imunisasi dan menghindari adanya KIPI. Sebelum pelayananimunisasi, petugas kesehatanwajibmenginformasikan secara lengkap tentang imunisasi, metode pemberian, manfaat serta kemungkinan adanya KIPI [5]. Pada masa pandemic
Covid-19, pelayanan imunisasi tetap diberikan dengan menerapkan prinsip PPI dan menjaga jarak aman $1-2$ meter. Hasil penelitian ini menunjukkan bahwa petugas kesehatan telah melakukan kegiatan pelayanan imunisasi sesuai dengan petunjuk teknis dari Kementrian Kesehatan [2] yaitu petugas kesehatan dan pengantar wajib memakai masker di tempat pelayanan kesehatan dan memastikan semua vaksin, logistik dan peralatan/kit anafilaktik tersedia dalam keadaan baik dan bersih, sedangkan indeks terendah yaitu menggunakan sarung tangan (bila tersedia), sarung tangan diganti setiap satu sasaran yang diimunisasi.

Keberhasilan program imunisasi ditentukan oleh cakupan imunisasi dan mutu pelayanan yang diberikan oleh petugas imunisasi. Terdapat bebarapa faktor yang mempengaruhi keberhasilan program imunisasi yaitu tingkat pendidikan dan usia ibu, dukungan keluarga dan masyarakat serta peran dari petugas imunisasi. Peran petugas kesehatan sangat penting dalam meningkatkan partisipasi masyarakat khususnya ibu yang mempunyai bayi/balita untuk dimunisasi [6] Pada tahun 2014, Lafond A dalam penelitiannya yang berjudul Driver of routine immunization coverage improvement in Africa, menemukan bahwa peningkatan cakupan imunisasi disebabkan oleh peran penting dari strategi pelaksanaan dan ketrampilan manajer lokal yang mampu menyesuaikan strategi khusus dengan kebutuhan masyarakat [7]

Penelitian ini menunjukkan bahwa cakupan imunisasi dasar lengkap dinilai dari indeks cakupan imunisasi per-antigen dari 46 orang,sebagian besar responden memiliki kategori kurang. Hasil penelitian didapatkan indeks cakupan imunisasi dasar lengkap tertinggi pada cakupan imunisasi HB0 dan indeks terendah pada cakupan imunisasi DPT 2 . Program imunisasi pada bayi mengharapkan agar setiap bayi mendapatkan kelima jenis imunisasi dasar lengkap yang meliputi HB0, BCG, DPT, Polio dan Campak. Keberhasilan seorang bayi dalam mendapatkan imunisasi dasar diukur melalui indikator imunisasi dasar lengkap[8]

Hasil analisis data menunjukkan bahwa tidak ada hubungan antara peran petugas kesehatan dengan cakupan imunisasi dasar lengkap selama pandemi Covid-19, bertolak belakang dengan penelitian penelitian yang telah dilakukan sebelumnya yang menyatakan petugas imunisasi berperan sangat penting dalam keberhasilan program imunisasi, yaitu ketika peran petugas kesehatan semakin tinggi pada pelaksanaan pemberian imunisasi maka pencapaian hasil cakupan imunisasi juga akan semakin tinggi [8]. Zakiyah dkk, dalam penelitiannya juga menyatakan bahwa terdapat hubungan antara perencanaan, 
pelaksanaan, monitoring dan evaluasi serta manajemen program imuisasi dengan cakupan imunisasi [3]. Penelitian ini tidak sejalan dengan teori yang menyatakan bahwa peran merupakan sikap atau perilaku yang diharapkan oleh orang lain terhadap seseorang sesuai kedudukannya dalam suatusistem. Keadaan sosial secara konstan merupakan salah satu yang mempengaruhi peran. Preskripsi serta harapan dari suatu peran merupakan dasar yang menerangkan keadaan yang harus dilakukan oleh individu-individu pada situasi tertentu agar tercapai harapan dari peran tersebut [8]

Keberhasilan program imunisasi ditentukan oleh bebarapa faktor yaitu tingkat pendidikan dan usia ibu, dukungan keluarga dan masyarakat serta peran dari petugas imunisasi. Meskipun petugas kesehatan berperan dalam meningkatkan partisipasi masyarakat khususnya ibu yang mempunyai bayi/balita untuk dimunisasi tanpa dukungan keluarga maka keberhasilan program imunisasi tidak bisa tercapai. Sumber dukungan terbesar dari individu adalah keluarga sebab ketika individu mengalami permasalahan maka keluarga menjadi tempat cerita, bertanya serta mengeluarkan keluhan yang dialami. Hubungan saling mempercayai juga berbentuk dalam keluarga. Pada masa pandemi Covid-19 ini individu akan lebih nyaman dan optimis dalam memenuhi kebutuhan psikologisnya jika mendapatkan dukungan keluarga yang tinggi [9], [10].

\section{KESIMPULAN}

1. Peran petugas kesehatan dalam memberikan pelayanan imunisasi dengan kategori "Baik" $(67,4 \%)$

2. Cakupan imunisasi dasar lengkap dalam kategori "Kurang" (71,7\%)

3. Tidak ada hubungan antara peran petugas kesehatan dengan cakupan imunisasi dasar lengkap selama pandemi Covid-19

\section{DAFTAR PUSTAKA}

[1] Sajuni, "Vaksinasi Measles, Mumps, dan Rubella (MMR) Sebagai Prophylaxis Terhadap COVID-19," KELUWIH J. Kesehat. dan Kedokt., vol. 1, no. 2, pp. 25-28, 2020. Kementrian Kesehatan Republik Indonesia, "Petunjuk Teknis Pelayanan Imunisasi Pada Masa Pandemi COVID-19," 2020.

[3] A. Zakiyah, S. Utami, C. Sandra Bagian Administrasi dan Kebijakan Kesehatan, F. Kesehatan Masyarakat, and U. Jember Jln Kalimantan, "Hubungan antara Peran Petugas Kesehatan dengan Cakupan Imunisasi per Antigen Tingkat Puskesmas di Kabupaten Jember (Correlation between Role of Health Officer with Antigen per Immunization
Coverage at Public Health Center in Jember Regency)," 2014.

[4] T. A. Diah Andika Sari, Rahmita Nurul Mutmainah, Ika Yulianingsih and M. B. Tarihoran, "Kesiapan Ibu Bermain Bersama Anak Selama Pandemi Covid-19, 'Dirumah Saja," J. Obs. J. Pendidik. Anak Usia Dini, vol. 5, no. 1, p. 373, 2020, doi:

10.31004/obsesi.v5i1.548.

[5] Kementrian Kesehatan Republik Indonesia, "Peraturan Kementrian Kesehatan Nomor 42 Tahun 2013 tentang Penyelenggaraan Imunisasi,” Вестник Росздравнадзора, vol. 6, pp. 5-9, 2017.

[6] D. Mamonto, A. Y. Ismanto, and S. Sibua, "Hubungan antara peran petugas kesehatan dengan cakupan imunisasi pada bayi usia 9-12 bulan di Puskesmas Bohabak dan Puskesmas Boroko," J. Stikergrahamedika, vol. 2, no. 2, pp. 11-17, 2019.

[7] A. LaFond, N. Kanagat, R. Steinglass, R. Fields, J. Sequeira, and S. Mookherji, "Drivers of routine immunization coverage improvement in Africa: Findings from district-level case studies," Health Policy Plan., vol. 30, no. 3, pp. 298-308, 2015, doi: 10.1093/heapol/czu011.

[8] I. Tiani et al., "Peran Petugas Imunisasi dalam Pemberian Vaksinasi Pentavalen The Role of Immunization Worker in Giving Pentavalen Vaccine," J. Ilmu Keperawatan, vol. 4, no. 1, pp. 2338-6371, 2016.

[9] P. D. Igiany, "Hubungan Dukungan Keluarga dengan Kelengkapan Imunisasi Dasar Correlation of Family Support with Basic Immunization Completeness," vol. 1, no. 1, pp. 67-75, 2019.

[10] N. U. Diharja, S. Syamsiah, and R. Choirunnisa, "PENGARUH PANDEMI COVID 19 TERHADAP KUNJUNGAN IMUNISASI DI POSYANDU DESA TANJUNGWANGI KECAMATAN CIJAMBE TAHUN 2020," vol. 1, no. 1, pp. 152-165, 2020. 